\title{
Hindi Protagonists of Science and Swadeshi in the First Half of the Twentieth Century
}

\author{
Dhrub Kumar Singh* \\ Department of History, Faculty of Social Sciences, Banaras Hindu University Varanasi.
}

(Received 15 June 2020; Revised 27 June 2020)

\begin{abstract}
This essay portrays some of the hitherto unknown protagonists of the first half of the 20th century who imbibed, radiated and reinforced the spirit of science and swadeshi by initiating science writings in Hindi. Their efforts enhanced and ensured accessibility to science for students, local entrepreneurs and the general public of the Hindi-speaking sphere that geographically and demographically constituted a large part of the subcontinent. Among the science writers including teachers and amateur entrepreneurs of this period were hitherto unknown individuals like Mahesh Charan Sinha, Lakshmi Chand, Pandit Tejshankar Kochak, Shankar Rao Joshi, Shitala Prasad Tiwari, Phuldeo Sahay Verma, Nihalkaran Sethi, Mukund Swarup Verma, Gorakh Prasad, Satyaprakash and Braj Mohan to name a few.
\end{abstract}

Key words: Allahabad, Banaras, Bhotiki, Gaṇita, Hindi writers, Krịịi, Prayag, Rasāyana, Science, Svāsthya, Swadeshi, Vigyan Parishad, Vijnana.

\section{Introduction}

The Swadeshi movement that had its genesis as a political movement was a protest to the Curzonian partition of Bengal in the first decade of the 20th century. The movement gradually transformed itself into an alternative spirit of self-reliance based on indigenous production, education and inculcation of science (Sarkar 1994; Bhattacharyya 1986). The agitational aspect of the Swadeshi movement may not have stirred the Hindi heartland in the aftermath of the movement in Bengal, but the spirit of Swadeshi manifested itself through the publication of science magazines, journals, and related literature in Hindi or Hindustani. This essay underscores the proliferating publication of Hindi tracts on science, technology, and medicine and documents instances of the inculcation of

DOI: 10.16943/ijhs/2020/v55i3/156956

*Email: singhdhrubkumar@gmail.com science through the mother tongue among the common masses.

\section{Rendering Science in Hindi: Some Unknown Protagonists}

In the first half of the 20th century, the spirit of Swadeshi was manifestly evident in the earnest efforts and engagements of individuals such as teachers and mentors associated with various amateur societies and institutions of higher learning. They made great efforts to render popular books and textbooks on science and mathematics in the vernacular for dissemination among Indian students and entrepreneurs. In this essay, evidences of both translations and independent rendering of textbooks and popular books on science that went through several prints and reprints in the first half of the 20th century have been highlighted by drawing upon the Hindi 
repertoire. The same spirit of Swadeshi was manifested in Bangla in which similar efforts were initiated much earlier, and by the early decades of the 20th century, had obtained maturity (Roy 2002). ${ }^{1}$ Among popularizers of Science and Swadeshi in Hindi were hitherto unknown individuals like Mahesh Charan Sinha (also referred to as Mahesh Charan Singh), Lakshmi Chand, Pandit Tejshankar Kochak, Shankar Rao Joshi, Shitala Prasad Tiwari, Phuldeo Sahay Varma, Nihalkaran Sethi, Mukund Swarup Verma, Gorakh Prasad, Satyaprakash and Braj Mohan to name a few. This essay attempts to recount the rudiments of their contribution in disseminating science through Hindustani or Hindi during this period.

\subsection{Mahesh Charan Sinha}

Mahesh Charan Sinha, professor of agriculture and craft at Gurukul Kangri University, Haridwar, had the distinction of rendering and presenting writings on physics, chemistry and botany in Hindi. He wrote three distinct books titled Rasayana-shastra, (Hindi Chemistry, 1909), Vanaspati-shastra (Hindi Botany, 1911) and Vidhyutshastra (Hindi Electricity, 1915), covering chemistry, botany and electricity respectively. The subject matter of these texts included basic ideas about atoms, molecules, gravity, gas, light, electricity, method of salt preparation, parts of plants and related aspects. ${ }^{2}$ Sinha's engagement was often innovative, for instance, at the end of the Rasayan-shastra, he compiled a short Rasayana- shastra kosha which was a brief compilation of terms related to chemistry coined in Hindi with their equivalence in English. This must have been a laborious exercise and implicit in this engagement was both having a knowledge

\footnotetext{
${ }^{1}$ Roy's compilation of science writings in the 19th century stands testimony to this. As far as rendering literature on science in Bangla was concerned, the great efforts of Ramendra Sundar Trivedi, the celebrated physics teacher and a creative disseminator of science through Bangla and Rabindranath Tagore's experiments to make Bangla the carrier of such ideas aided such efforts in the late 19th and early 20th century. It must be noted that Tagore himself wrote Vishva Parichay and dedicated it to the celebrated physicist S. N. Bose (Dwewedi, 1937). For Ramendra Sundar Trivedi, see Chacraverti, 2000.

${ }^{2}$ Mahesh Charan Sinha (Singh) also published several articles on aspects of science in various Hindi journals of the time like Saraswati (1910) Vijnana (1917) Madhuri (1926). The anthology Hindi mein Vigyan Lekhan ke Sau Varsh is a compilation of select articles on popular science in Hindi written by individuals like Mahesh Charan Sinha and his contemporaries by Shiv Gopal Mishra in two volumes (Mishra 2001, 2003).
}

of chemistry or chemical sciences and the ability to make Hindi amenable for creating, crafting and coining equivalent scientific terms (Sinha 1909). These books lucidly presented the knowledge of science and technology to the literate public and particularly drew the attention of students. They ran into several reprints which explains the viability, utility and the importance of these writings for native students of Hindi medium and for local readers as well. Mahesh Charan Sinha was born in Lucknow in 1882 and obtained his B.A. from the University of Allahabad. Subsequently, motivated by an advertisement in the Advocate about a scholarship to pursue technical education in Japan by a Sindhi seth, Wasu Mull, Sinha with great difficulty undertook a journey to Japan. Unfortunately for him, on meeting the Japan based merchant he discovered that the latter had instituted no such scholarship (Carroll 1979 pp. 293-94,)! ${ }^{3}$ Unfazed, Sinha persevered for a year in Japan acquiring technical skills like umbrella and hosiery making and then moved to America where he enrolled himself for a degree at the prestigious Oregon Agricultural College in Corvallis (Carroll 1979 p. 294). After returning to India, Sinha worked in various capacities that included his stint as principal of a college named the Prem Mahavidhalaya at Vrindavan. Subsequently, given his training in agriculture, he joined the newly established Gurukul Kangri University, a native, nationalist and Arya Samaj institution at Haridwar, as professor of agriculture and botany. The institutional history of Gurukul Kangri attests to his presence among the initial group of teachers and to his role in bringing out science publications in Hindi (Gurukul Kangri Visvavidhalaya ka Sanshipt Itihas, 1901-1930, year? pp. 10-11). ${ }^{4}$ The others in this initial group were Sathe, Sriyukt Govardhan, Ramsharandas Saxsena, Prannath, Balkrishna, and Sudhakar (ibid p. 10). By choice and as an expression of the ideals of the Gurukul, its initial founders took

\footnotetext{
${ }^{3}$ Carroll informs, Wasu Mull objected to the misrepresentation of his intentions by the Advocate's Editor Ganga Prasad Verma who had advertised the scholarship in his name.

${ }^{4}$ This short and succinct history provides a glimpse of a particular shade of the national education experiment that was initiated at $\mathrm{Gu}$ rukul Kangri. Instruction in Hindi at college and university levels where none had existed was one of the enduring contributions of $\mathrm{Gu}$ rukul Kangri. At a time when there were no books especially in various science subjects and mathematics in Hindi, the founding teachers of Gurukul Kangri rendered textbooks on these subjects in Hindi to fill the void. Mahesh Charan Sinha was one of the initial teachers who wrote textbooks on science in Hindi.
} 
upon themselves the arduous responsibility of bringing out science textbooks in Hindi. Perhaps, the complementarity that existed among this initial group of teachers at the Gurukul gave further agency to the need for popularising and disseminating science through publications in Hindi. This endeavour was further undertaken by individuals and institutions founded under the aegis of national education and Swadeshi in slightly different contexts and in other regions of the country as well. As part of his science publication efforts, Sinha also tried to establish a joint stock company to bring out science books in Hindi. At the end of his book on Hindi Chemistry, Sinha shared something unique and interesting in the form of an appeal to Hindi lovers and prospective readers and users of the book that he had rendered so laboriously and diligently. This appeal is interestingly captioned 'vigyāpana' or advertisement and begins with the admission that many readers have been writing and requesting him to also render books of physics and agriculture in Hindi. Such repeated requests, Sinha construed, was an encouraging proof that Hindi knowing students and literati were becoming more inclined towards pursing science, and was a sure sign of people awakening from their inertia and slumber. To practically realise the goal of rendering books in Hindi on various aspects of science, Sinha argued, a number of assistants and a rich library would be required and a corpus fund was sine qua none (Sinha, 1909). In the Swadeshi spirit of the times, Sinha came up with the unique idea of floating a joint stock company worth a lakh of rupees to sustain the endeavour on a long term basis. He appealed to science and Hindi lovers imbued with the Swadeshi spirit to purchase shares of this company with the minimum value of each share being five rupees. The company could only take off if two thousand cooperative shareholders were to come forward to invest. Sinha's proposal to serve the cause of Hindi and science is truly insightful and instructive of the innovative spirit of the Swadeshi era. Induced as he was with the spirit of swadeshi, Sinha's proposal of a share holding company to realise the goal of rendering books in Hindi actually underscored the fact that he could see far and beyond. Both in the pre-project era of academic funding and in contemporary times, this stands as a unique and unheard of venture. Sinha's technical training also led him beyond a purely academic engagement to prepare a wireless telegraphy or telephone in 1911 that worked satisfac- torily at short range and was not an imitation of any other machine. ${ }^{5}$ Amidst the Swadeshi movement, he noted that in order to develop scientism or the spirit of sciencevetta among common Indians, writing in the mother language and the search for indigenous knowledge were both important (Sinha 1909, p. 2). ${ }^{6}$ As he noted in his article 'India and the Outside World', 'knowledge of one's own powers and capabilities is as much necessary for further improvement as the knowledge of one's weaknesses (Sinha 1908, p. 48).

\subsection{Lakshmi Chand}

Another individual who tried to initiate and inspire the inculcation and cultivation of science along with smallscale but sustainable Swadeshi industries was the amateur and self-styled Lakshmi Chand (also referred to as Laxmi Chand). His full biographical details are not known (death about 1922), however, he seemed to have earned an impressive array of degrees as attested by his popular tracts. The title page of his book reveals that besides a masters from Allahabad University, he earned an M.Sc. from Victoria, England, F.C.S. (London), A.M.T. (Manchester) and was a medallist of the City and Guilds of London Institute. The title page of his book also informs us that he became a professor of applied chemistry in Baroda state. He was a self-styled publicist of the Vigyan $\mathrm{Hu}$ narmala series of publications that published books on science based skill and everyday technologies in Hindi.

Lakshmi Chand was a popularizer of skill-based industrialism who advocated the deployment of 'everyday technology' for the production of daily use products on a modest scale. His Hindi tracts and pamphlets on skill-based commodities like soap, detergents, dyes, and ink made him an important author, populariser and enthusiast of the Swadeshi and scientific spirit. As part of a science series in Hindi, Lakshmi Chand published several books like Roshnai Bnane ki Pustak i.e. a book on ink making in 1915 that was reprinted in 1916, 1918 and 1931. His other books were Sughandit Sabun Bnane ki Pustak (1915) on manufacturing scented soap which also ran into several reprints; Tel ki Pustak (1916) i.e. a book on aspects of oil processing, and Tantukala (1922) on the art and craft of textiles and weaving. He also edited Rang ki Pustak

\footnotetext{
${ }^{5}$ The Hindustan Review, vol. 23, 1911, p. 230

${ }^{6}$ The Hindustan Review, Jan. 1908.
} 
(1916) and Warnish aur Paint (1917) which were books on colour and dye, and varnish and paint manufacture. ${ }^{7}$ All these books were brought out by the Vigyan Hunarmala office at Banaras, the phrase 'vigyan hunarmala' literally meaning tracts on science-based skills. Essentially, these tracts were writings on everyday technology but were presented as disseminating and popularising science-based entrepreneurial production. His books appeared to have been widely popular as some of them ran into several reprints within a short span of time. As is attested by their reprints, they were popular not because of their entertainment value but their utility and popularity were based on the fact that these booklets and tracts acted as manufacturing guides and primers for those small-scale native entrepreneurs who wanted to manufacture these commodities on a sustainable scale for Indian consumers. The products were meant for those consumers whose economic location was such that, for them, similar imported European commodities adorning elite city stores were unaffordable.

As evident, these books and tracts were printed and reprinted in the immediate years that followed the ebbing away of the Swadeshi movement as a political movement. It is also a curious fact that Lakshmi Chand's writings appeared at the same time when, in the context of the First World War (WWI), the Indian Industrial Commission (1916-18) was created to reflect upon and recommend on the nature and scope of industries in India in the larger context of the industrial role of India for the imperium. ${ }^{8}$ The long-drawn war made it amply clear to the metropolis that the colony must also have an industrial role to aid the empire. A colony like India was to acquire a subservient industrial role for industrialized Britain as exigencies like war production in the colony during WWI had made it apparent. It is in this wider context that one has to underline and appreciate the science-swadeshi

\footnotetext{
${ }^{7}$ Lakshmi Chand, Roshnai Bnane ki Pustak, 1915; Hindi Science University Mala, No. I, Devi Prasad Agrawal, Vigyan Hunar Mala Office, Banaras City, 1930 (4th reprint); Sughandit Sabun Bnane ki Pustak, 1915, Vidya Vilas Press, Banaras City, 1930 (4th reprint); Tel ki Pustak, Hindi Science University Mala, No. III, Vigyan Hunar Mala Office, Banaras City, 1916; Rang ki Pustak (ed.) 1916, Published by Devi Prasad Agarwal, Shri Lakshmi Narayan Press, Banaras City, 1919 (2nd edition); Warnish aur Paint (Raughan Sazshi) (ed.), Vigyan Hunar Mala Office, Banaras City 1917 and Tantukala, Vigyan Hunar Mala Office, Banaras City, 1922.

${ }^{8}$ Report of the Indian Industrial Commission, 1916-18, Calcutta, 1918.
}

spirit of Lakshmi Chand. Here was a man of Hindi heartland who was publishing tracts, which David Arnold describes as 'everyday technology', for infusing and incubating science based small-scale sustainable industrialism (Arnold 2013).

\subsection{Sukhsampatti Rai Bhandari}

Like Mahesh Charan Sinha and Lakshmi Chand, Sukhsampatti Rai Bhandari (born in 1895), a journalist and the proprietor of the Dictionary Publishing House from Jaitaram area of Rajasthan, also wrote in Hindi to create awareness about Indian scientists and their inventions. Bhandari was a man of many parts though he made a mark as an illustrious journalist serving as editor of several regional newspapers like Ventakeshwar Samachar in 1913, Sadharma Pracharak in 1914, Patliputra in 1915, Mallari Marthand/Marthad in 1916, Naveen Bharat in 1923 and most importantly the agricultural magazine Kisan from 1926 to 1930 (Kapoor and Tandon 1951, p. 322). He was also the editor of an English-Hindi dictionary that ran into seven volumes. ${ }^{9}$

Notwithstanding his journalistic engagements, Bhandari was keenly interested in science, especially agricultural science. His book Vigyan aur Avishkaar was a treatise on science and inventions published in 1919 (Bhandari 1919). He also wrote a text called Sulabh Krishishastra, on agricultural practices in the country (Bhandari1932). According to Bhandari, none other than Lala Lajpat Rai and scores of other agriculturists, and men of agricultural sciences in India welcomed and recommended his Sulabh Krishi-shastra. He also duly acknowledged the works of his contemporaries, Pandit Tejshankar Kochak and Shankar Raoji Joshi and agricultural experts like Howard (Indore Plant Research Institute), Mann (Director of Bombay Agricultural Department), Allen (Principal of Nagpur Agricultural College), and John Keno's work on intensive farming in India in his writings. Bhandari definitely consulted dozens of books on agricultural sciences from various regions in order to distil their essence and wisdom in his own book on agriculture.

\footnotetext{
${ }^{9}$ This dictionary was published by his Dictionary Publishing House at Ajmer.
} 


\subsection{Other Science and Swadeshi Protagonists}

The Swadeshi agenda to popularize the use of sciencebased small technology in the field of agriculture was simultaneously initiated by Pandit Tejshankar Kochak, Shankar Raoji Joshi and Shitala Prasad Tiwari. Born around the year 1880, after obtaining his B.Sc. and P.A.S., Pandit Kochak worked as lecturer at Agricultural College, Kanpur and also officiated as Agricultural Chemist to the Government of United Provinces. Thereafter, he became the Principal of the Government Agriculture School at Bulandshahr and authored various books titled Paimaiash (on measurement, 1919), Kapas aur Bharatvarsha (on Indian cotton, 1920), ${ }^{10}$ and Krishi Shastra (on agriculture, 1924, 3rd edn.). Shankar Rao Joshi, a resident of Lucknow, was an agricultural officer who was associated with the Vigyan Parishad, Allahabad and its mouthpiece the Vijnana. ${ }^{11}$ He wrote articles on agricultural sciences, gardening, insects (on Jhingur, Tiddi etc.) and authored several books including Varsha aur Vanaspati (on rainfall and plants, 1923), Kalam Paiband (on grafting, 1940) and Udyana (on gardening, 1948, 3rd edition). ${ }^{12}$

Another intellectual, Shitala Prasad Tiwari, the translator of Meston Agriculture Book and the editor of Kisanoparak, was an assistant farm supervisor of the Agricultural Institute, Allahabad. He also taught agriculture at Hindi-Vidyapith and Hindi Sahitya-Sammelan. His book Krishi-Vigyan (on agricultural science, 1926), volume one, a tome of 900 pages, was introduced by H.N. Batham, the Agricultural Chemist to the Government of United Provinces (Tiwari, 1926). ${ }^{13}$ C.S. Mishra, the first Assistant Imperial Entomologist, translated Bulletin No.

\footnotetext{
${ }^{10}$ Pandit Tejshankar Kochak, Paimaiash (1919), Kapas aur Bharatvarsha (1920), See Gupta, 1945, pp. 156-58.

${ }^{11}$ As per Shiv Gopal Mishra, Vijnana, the monthly magazine of the Vigyan Parishad began to be published from 1915. However, B. K. Sen dates the magazine to the 1913, which was the founding year of the Vigyan Parishad. See, Mishra 2003, 'Introduction' and Sen 2017, pp. 205-06.

${ }^{12}$ See also Vijnana, vol. 15, Apr-Sept. 1922; 'Vatavaran', Saraswati, November 1923, in Mishra (ed.), 2001, vol. 1, pp. 131-40. Also see 'Chandra Prakash aur Vrikshon per Prabhav', Vijnana, Jul-Sept. 1950, in Mishra (ed.), vol. 2, 2003, pp. 410-11.

${ }^{13} \mathrm{H}$. N. Batham or Har Narayan Batham who was an agricultural chemist in United Provinces is not to be confused with another illustrious man of science namely Sam Higginbottom, the founder of Allahabad Agricultural Institute which is the present day Sam Higginbottom University of Agriculture, Technology and Sciences (SHUATS). Higginbottom was close to Madan Mohan Malaviya and had advised him to open up the Faculty of Agricultural Sciences at BHU.
}

28 of Agricultural Research Institute Pusa that dealt with Lac (Mishra 1914). Apart from the individuals discussed, there were many others who wrote about various aspects of agriculture and farming though their biographical details are not known. These writings reflected a growing consensus on the importance of modern science in in creasing production and productivity in agriculture and were definitely an indication of a 'growing conviction among the Hindi intelligentsia that modern methods and scientific techniques of cultivation constituted an important aspect of agricultural modernization (Baksi 2016, pp. 98-122, Mishra 2004).'

\section{Popularising Science and Industrialism through Hindi Print}

In the 1930s, the attempts to spread scientific information, knowledge and consciousness about human anatomy, elementary physics, chemistry, craft and technology were also undertaken by students, teachers, and professionals associated with institutions of higher learning such as Banaras Hindu University and University of Allahabad. Among them, Phuldeo Sahay Varma, Nihalkaran Sethi, Mukund Swarup Verma, Satyaprakash, Gorakh Prasad and Braj Mohan were prominent. These scholars wrote scientific books in Hindi with a motive to spread science both among students and the masses.

\subsection{Phuldeo Sahay Varma}

Phuldeo Sahay Varma, was born in 1889 in Saran district, Bihar and obtained various educational qualifications including a masters in chemistry from Presidency College, Calcutta University and higher qualifications like A.I.I.Sc. from Indian Institute of Science, Bangalore (Mani, 1997, p. 20). As an impressionist student at Calcutta, teachers like P. C. Ray made deep impact upon him. Similarly, at I.I.Sc. he must have had occasion to intimately interact with J. J. Sudborough, the head of the amalgamated Department of Chemistry (Subbarayappa, 1992, pp. 8990). He eventually joined Banaras Hindu University and became a renowned chemistry teacher. Apart from his research publications and books in English, he rendered several books in Hindi to enhance the scope of science for students. His writings include the Sadharana Rasayana, a two volume textbook on general chemistry, published as 
part of B.H.U. Granthmala series in 1932 and Prarambhik Angarika Rasayana, a textbook on elementary organic chemistry published in 1948 (Varma 1932, 1948). He authored a utilitarian and inquisitive book titled Mitti ke Bartan published in 1939 dealing with the raw materials, processes and machinery related to the manufacture of clay, stone and porcelain utensils (Varma 1939). He also published several popular articles on topics like food ( $\bar{a} h \bar{a} r a)$ and problems of nutrition (khādya samasyā) in the Vijnana and other popular Hindi magazines of the time. ${ }^{14}$ In his mature years, looking back at his life as an organic chemist and to fuel young minds fired with scientific curiosity, Varma wrote a series of popular but dense books on various chemical products that had revolutionized Indian industry and life. In this genre the various books were on petroleum, plastic, lac (Lakh aur Chapra), fertilizer (Khaad aur Urvarak), coal (Koyla), and sugarcane and sugar (Ikh aur Chini) (Mani 1997, p. 25).

Varma was also involved in preparing a dictionary of scientific terms. As assistant editor to the Scientific Terminology section of the Nagari Pracharani Sabha, Banaras, he compiled the Hindi Vaigyanik Shabdawali: Rasayana Shastra (Varma 1930). Besides his academic engagement, he was also associated with the journal Vijnana of Vigyan Parishad, Allahabad and served as its president and vicepresident. ${ }^{15}$ Varma served science and Hindi and in turn served one of the ideals of national education, which was to propagate science through the mother tongue. As a compiler of dictionaries of scientific terms and as author of textbooks and popular books on science and craft he served the cause of science and Swadeshi (Kapoor and Tandon 1951, p. 152).

\subsection{Nihalkaran Sethi}

Varma's contemporary and colleague, Nihalkaran Sethi (or Nihal Karan Sethi) also contributed to the science and Swadeshi cause in a distinct way. After acquiring his M.Sc. and D.Sc., Sethi begun his career in physics at Banaras Hindu University. He was also elected Fellow of the Indian Academy of Sciences in 1935. Sethi was further involved in preparing the Hindi vocabulary for scientific terms in physics as part of Prakirnak

\footnotetext{
${ }^{14}$ See 'Aahar', Ganga, January 1934, in S.G. Mishra (ed.), vol. 2, 2003, pp. 211-17; 'Khadya Samasya', Hindustani, 1946, in S.G. Mishra (ed.), vol. 2, 2003, pp. 340-52.

${ }^{15}$ Vijnana, vol. LXXXIX, no. 1, Apr. 1959.
}

book series which was approved by the Kashi Pracharini Sabha's Committee of Word Definition. His books included, Prarambhik Bhotik Vigyan (elementary physical sciences, 1930) Hindi Vaigyanik Shabdawali: Bhotik Vigyan (compendium of Hindi scientific terms pertaining to physics or physical sciences, 1929), and Chumbakatava aur Vidhyut (magnetism and electricity, 1960) (Sethi, 1930, 1948, 1960). Sethi further collaborated with the distinguished teacher of chemistry at Allahabad University, Satyaprakash and authored a book on the standardisation of scientific weights and measures from Vigyan Parishad titled Vaigyanik Pariman (1928) (Sethi and Satyaprakash, 1928). Like his colleague, Phuldeo Sahay Varma, Sethi too was involved in preparing a compendium of Hindi scientific terms for the Nagri Pracharani Sabha and compiled the Hindi Vaigyanik Shabdawali: Bhotik Vigyan (Sethi 1929). Again like Phuldeo Sahay Varma, he remained associated with the Vijnana and published several popular articles on scientific themes like theory of light (prakāśa), vision (drști), electricity (vidyuta) and electrification (vidyutìkarana) in the journal (Sethi 1917, pp. 99-102; 1918, pp. 155-63; 1918, pp. 245-50; 1919, pp. 30-35). Sethi was not just an author of university level textbooks in Hindi and a popular writer on aspects of physics in Vijnana, but was a well posted physicist in his own right. His research articles also appeared in journals like Physical Review published by the American Physical Society (Sethi 1924; Bhargava 2008, pp. 1206-07). ${ }^{16} \mathrm{He}$ was with the Banaras Hindu University from its inception and must have soiled his hands in the Swadeshi spirit of institution building in creating the rudiments of the physical laboratory at BHU. Sethi later served Agra College both as a teacher and as its Principal.

\subsection{Mukund Swarup Verma}

Mukund Swarup Verma, born in 1896 at Sikandarabad, obtained his M.Sc. and M.B.B.S. degrees and became the Chief Medical Officer at Banaras Hindu University. He also wrote on science, health and anatomy in Hindi with the aim of spreading and supporting scientific knowledge and awareness among students of medical colleges, medical schools in particular and the literate masses of northern India. His publications included Shishu Palana (na-

\footnotetext{
${ }^{16}$ It is also to be noted that Pramod Karan Sethi, the famous orthopaedic who created the Jaipur Foot was the illustrious son of Professor Nihalkaran Sethi, the physicist.
} 
tal care, 1925), Swasthya Vigyana (health and hygiene, 1931), Manava Sharira Rahasya (anatomy, 1928), Visha Vigyana (science of poison, 1932), and Manava Sharira Rachana Vigyana (anatomy, 1938).

\subsection{Satyaprakash}

Various individuals at Allahabad were also involved in disseminating and popularizing science among the literate masses. The contributions of Satyaprakash (or Satya Prakash) and Gorakh Prasad in this regard are particularly noteworthy. After obtaining his M.Sc. and F.I.C.S., Satyaprakash taught chemistry at Allahabad University and also served as the Editor of Vijnana in the 1930s. Satyaprakash was a historically inclined scientist and, in some sense, he was a savant in the footsteps of Acharya P.C. Ray. As a young teacher of chemistry he must have derived inspiration from Nil Ratan Dhar's enduring presence as a towering figure of chemistry at the University of Allahabad. Satyaprakash also empathized with the craft and chemical traditions of India and the synergy between them. Even when he wrote textbooks he took care to preface them by providing a panoramic view of the Indian tradition of chemistry. He also aspired and desired for chemical science to be utilized in the refinement of everyday technologies for manufacturing commodities and wage goods. He shared the larger vision of P.C. Ray in the application of chemistry to remedy unemployment by creating entrepreneurship, employment and self-reliance. Satyaprakash collaborated with Nihalkaran Sethi, the physicist and Gorakh Prasad, the mathematician along with many of his peers to sustain the Vigyan Parishad at Allahabad and its mouthpiece, Vijnana. He wrote popular textbooks on inorganic chemistry in Hindi like the Sadharana Rasayana and Samanya Rasayana Shastra for students at college and university levels (Satyaprakash 1929, 1951). He also authored historical treatises like Prachin Bharat mein Rasayan ka Vikasa, which is a classic text also used by erudite Ayurveda Acharyas as a refined and sophisticated exposition of alchemical and chemical traditions as codified in various ancient texts (Satyaprakash 1954, 1960).

Apart from these dense textual treatises, Satyaprakash also rendered Shrishti ki Katha (1937) published from Hindi Sahitya Samelan, Prayag. This was part of a different genre of books written by Satyaprakash. Shrishti $k i$ Katha is an exposition of the evolution of the universe including planet Earth with its human and other living inhabitants and the ways of their habitations. He was also the chief Editor of a multi-volume English to Hindi dictionary of scientific terms i.e. Vaigyanik Shabd Kosha brought out by the Bharatiya Hindi Parishad, Prayag (1948). ${ }^{17}$ Satyaprakash's oeuvre through this diverse genre of writing, apart from his role as professor of chemistry and as author of numerous research papers made him the initiator, inspirer and teacher par excellence for generations of students who pursued science as a vocation and profession.

\subsection{Gorakh Prasad}

Gorakh Prasad was born in 1896 at Gorakhpur, obtained his D.Sc. from Edinburgh, FRAS, and worked as a Reader at Allahabad University. More than these formal degrees, it is important to note that he was a pupil of the doyen of Indian mathematics Ganesh Prasad. Ganesh Prasad himself was the bearer and carrier of the tradition of mathematics from Bapu Dev Shastri and Sudhakar Dwivedi. Gorakh Prasad intimately worked with Ganesh Prasad at Banaras in the initial years of the Banaras Hindu University. As a teacher of mathematics at Allahabad University, he also served as the editor of Vijnana ${ }^{18}$ and authored books and articles on diverse topics such as Photography (1931), Saur Parivar (on the Solar system, 1931), Lakdi ki Polish (on wood polish, 1940) and Aakash ki Sair (1937). ${ }^{19}$ Gorakh Prasad as a mathematician, on the one hand, wrote comprehensive textbooks on higher mathematics (especially differential and integral calculus) for students at graduation and post-graduation levels with an enduring shelf life, on the other hand, he along with the celebrated chemist Satyaprakash, edited and compiled books on strategies and skills to produce everyday commodities related to soap, ink, varnish, dye and materials related to

\footnotetext{
${ }^{17}$ The editorial board of this series also had as its members Nihalkaran Sethi (Physics), Phuldeo Sahay Varma (Chemistry), Braj Mohan (Mathematics), Mahavir Prasad Srivastava (Astronomy), Gyanprakash Dube, Krishna Bahadur and Satyaprakash (Zoology and Botany).

${ }^{18}$ Vijnana, vol. 56, Oct. 1942-Mar. 1943.

${ }^{19}$ According to Gorakh Prasad, this popular, utilitarian and skill enhancing book was written in cooperation with a gentleman named Ram Yatanji as mentioned in his introduction to his Lakdi ki Polish; Aakash ki Sair, Allahabad: Indian Press, 1937. Also see 'Samay', Saraswati, August, 1923 in S. G. Mishra (ed.), vol. 1, 2001, pp. 123-30. See also, Gorakh Prasad's essays on photography in 'Photo Chapna', Vijnana, vol. 54, Oct.-Mar. 1941-42, p. 122.
} 
photography. Such skills (hunar) and useful recipes (upyogi nuskhe) were meant to be handy in everyday life and vocation. This was a parallel vocation which they enthusiastically tried to popularise not only by compiling books but also through essays in the Vijnana.

As an Editor of Vijnana in the early 1940s, Gorakh Prasad wrote several popular articles on aspects of craft and Indian tradition of industrialism. It was through $V i j$ nana that he also informed readers about the latest news and information from the world of science and scientists. These teachers of higher science and mathematics, with as much indulgence and passion, endeavoured to foster and promote craft and everyday commodity production by fortifying such skills through science and everyday technologies. The apostles of Big Science after 1940s pejoratively dubbed this applied science of nuancing and refining everyday technologies and craft as 'Wax and Sealing Science'. Perhaps charmed by spectacular and high instrumentation science and the promises it held, these apostles of Big Science did not appreciate the earnestness of university professors of science and mathematics like Gorakh Prasad and Satyaprakash who went beyond the precincts of their university labs to address concerns of youth unemployment by propagating science based manufacturing and skills. In a way, these men were carrying forward the ideals of one of the tallest Gandhian and humanistscientist of the country, Acharya P.C. Ray, who wanted to make science in general and chemistry in particular a catalyst for industrialism and manufacturing as a means of employment and self-employment that would lead to productive and pecuniary self-reliance of the youth.

\subsection{Braj Mohan}

An important contributor in the field of mathematics was the passionate practioner of mathematical science and teacher of high caliber, Braj Mohan (or Brij Mohan). He took upon himself the responsibility of not only writing and publishing mathematical tracts in Hindi but also mastered the art of teaching and disseminating mathematical ideas and concepts in Hindi. Braj Mohan was born in 1908 in Moradabad, completed his masters from Agra, and obtained a doctoral degree from Liverpool. In 1934, he joined the mathematics department at Banaras Hindu University where he taught until his retirement. He also served as principal of the Central Hindu College of the
B.H.U. (Mohan 2016, pp. 271-75). ${ }^{20}$ Despite being a mathematician, Braj Mohan had an enduring passion for Hindi, and in this sense, he served the cause of both Science and Hindi. Like many of his contemporaries and colleagues at his university, Braj Mohan argued for the teaching of scientific and technical subjects, especially mathematics in the mother tongue. He recognised and particularly pointed out the lack of proper scientific terms and expressions in Hindi and the inadequacy of the Nāgari alphabet for printing and typesetting. Throughout his years of academic engagement, Braj Mohan suggested numerous reforms for the incorporation of mathematical symbols, special signs and operations in Hindi typesetting and printing. Among his award winning publications on the rendering of mathematics in Hindi, the Ganitiya Kosha stands as a singular contribution (Mohan 1954). His other Hindi publications include Thosa Jayamati (on Solid Geometry, 1945), Niyamaka Jyamiti (on Co-ordinate Geometry, 1951) and Ganita ka Itihasa (history of mathematics, 1965). ${ }^{21}$

\subsection{Women Writers}

One also gets a glimpse, even if rather limited, of science writings and publications by women during the Swadeshi era. Chandrakanta Devi, a lecturer at Allahabad Medical College of Homeopathy wrote on health science (Devi 1933). The first edition of her book titled Swasthya Vigyana published in 1933 ran into a thousand copies. This book is an exhaustive companion on food, lifestyle, sanitation and aspects of general disease and affliction. It does not specifically touch on homoeopathy but is a general guide to healthy living for a family. Lakshmi Chand became the publisher of the book titled Tantukala in 1922 authored by her late husband Lakshmi Chand (1922). The names of women writers like Suman, Radha Pant, Chandrika Prasad, Neera, Rani Tandon (1945, pp. 73-80), Kamala Sadgopal, Prabha Asthana, Nalini Sen, Shanti Guhi and Shakuntala Verma sporadically appear in the

\footnotetext{
${ }^{20}$ This collection of supernatural stories was written by Brij Mohan at a ripe age and published posthumously by his son. At the end of the book, a brief though insightful biodata of the author has been compiled citing his numerous contributions and achievements.

${ }^{21}$ In this historical treatise, Braj Mohan highlights the contribution of Indian mathematics and mathematicians while surveying the larger history of mathematics across continents and civilizations. Several of his Hindi books have been reprinted by Vani Prakashan and are still in use today.
} 
pages of science and literary magazines, although they remain largely unknown. They wrote on diverse themes related to science ranging from gold, numbers, salt preparation, microbes, cultivation of pearls, fruit and vegetable preservation, properties of vegetables and their uses and sensory organs. ${ }^{22}$

\section{Conclusion}

Common among all the individuals discussed above of the Swadeshi era from Mahesh Charan Sinha in chemistry to Nihalkaran Sethi in physics and Braj Mohan in mathematics was the endeavour to coin scientific terms in Hindi and widen the repertoire of Hindi scientific terminology. They tried to tease out, forge and synthesize words in Hindi for processes, events, phenomena and various types of calculations in science and mathematics. They contributed in their own way to make Hindi amenable to carry forward scientific ideas and concepts. Braj Mohan even struggled with type setting of Hindi letters or blocks to make them amenable to represent mathematical notations and symbols. They did not succumb to the prevailing shortcomings of the language, but from within it, they tried to resolve them. Such sustained efforts could deliver in the era of science and Swadeshi.

Books on mathematics, physics, chemistry and botany in Hindi created confidence among students to apply and opt for science subjects at college and university levels. Vernacular primers about scientific production of everyday commodities and goods by both professionals and amateurs who had scientific and technical credentials to author such books testify to their engagement with the spirit of science, Swadeshi and industrialism. Mata Prasad Gupta, a lecturer at the Department of Hindi, University of Allahabad, compiled a list of science books rendered or published in Hindi (Gupta 1945). The production, proliferation and popularity of these books are clearly manifested by the multiple reprints they ran into. The proliferation of popular writings on science during the Swadeshi era is further attested by the numerous popular articles that appeared in the pages of literary magazines like Saraswati, Madhuri and Sudha, apart from the

\footnotetext{
${ }^{22}$ Mishra's compilation has articles by these women writers on the themes mentioned. See S. G. Mishra (ed.), vols. 1 \& 2, 2001 \& 2003 respectively.
}

science magazine Vijnana..$^{23}$

It is more than evident that the contribution of the individuals discussed, influenced as they were by the spirit of Swadeshi, not only opened avenues for students to enter colleges and universities to pursue science, but also animated science based skill and industrialism beyond the four walls of scientific labs. These struggles and contributions of the protagonists need to be documented and recorded in historiography. Their writings clearly indicate the fact that the attempts to engage with modernity on one's own terms, and the search for alternative ways of knowledge dissemination in the Hindi public sphere were shaped through the publication of these popular scientific writings in Hindi or Hindustani. Coeval to these processes, a few inclined individuals also went on to establish institutions and societies that started the publication of journals and magazines to systematically create awareness among Indians about the developments in natural sciences, mathematics, aspects of medicine, and agricultural sciences.

The proliferation of science and mathematics textbooks and popular books in Hindi surveyed in this essay appeared from various Hindi series brought out by different publishers and samitis or societies of the period. Despite the number of books cited here does not present an exhaustive sample, one still comes across various series like Hindi Science University Mala Series, Holkar Hindi Granthmala Series, Hindu Viswavidhyalaya Granthmala Series, Prakirnak Pustakmala Series, Manoranjan Pustakmala Series, Sahitya Suman Mala Pushp Series and Hindi Samiti Granthmala Series of which these books were a part of. One can then plausibly argue that the books cited were not stray publications but were part of a planned effort to serve science, Swadeshi and industrialism through Hindi.

\footnotetext{
${ }^{23}$ At the end of his second volume, Shiv Gopal Mishra has compiled a list of articles on science that came out in literary magazines like Sarawati, Madhuri and Sudha in the first half of the twentieth century. Between 1900 and 1939, the Saraswati published 343 science related articles. A list of 50 science articles has been compiled from the Madhuri though the exact years are not given; and from 1928 to 1941, a list of 54 science related articles appeared in the Sudha. Another magazine Vishal Bharat, saw the publication of 158 science related articles between 1930 to 1950. See Mishra (ed.), 2003, vol. 2, pp. 412-23.
} 


\section{Acknowledgement}

In the context of COVID 19, I am grateful to Dr Gautam Chandra for the help he provided.

\section{Bibliography}

[1] Arnold David. Everyday Technology: Machines and the Making of India's Modernity, The Chicago University Press, Chicago, 2013.

[2] Baksi Sandipan. The Hindi-speaking intelligentsia and agricultural modernisation in the colonial period, Review of Agrarian Studies, 6.2 (2016): 98-122.

[3] Bhandari Sukhsampatti Rai. Sulabh Krishi-Shastra, Kisan Karyalaya, Indore, 1932.

[4] Bhandari Sukhsampatti Rai. Vigyan aur Avishkar, Holkar Hindi Granth Mala No. 6, Shri Madhya Bharat Hindi Sahitya Samiti, Indore, 1919.

[5] Bhargava Rakesh. P. K. Sethi (1927-2008), personal news, Current Science, 94.9 (2008): 1206-07.

[6] Bhattacharyya Amit. Swadeshi Enterprise in Bengal, 1900-1920, INA Press, Mita Bhattacharyya, Calcutta, 1986.

[7] Carroll Lucy. The sea voyage controversy and the kayasthas of north India, 1901-1909, Modern Asian Studies, 13.2 (1979): 265-299.

[8] Chacraverti Santanu. Ramendrasundar Trivedi: a path-breaking populariser of science in Bengal, In Narender K. Sehgal, Satpal Sangwan and Subodh Mahanti (eds.), Uncharted Terrains: Essays on Science Popularisation in Pre-Independence India, Vigyan Prasar, New Delhi, 2000, pp. 76-88.

[9] Chand Lakshmi. Sughandit Sabun Bnane ki Pustak, 1915, Vidya Vilas Press, Banaras City, 1930, 4th reprint.

[10] Chand Lakshmi. Roshnai Bnane ki Pustak, 1915, Hindi Science University Mala, No. I, Devi Prasad Agrawal, Vigyan Hunar Mala Office, Banaras City, 1930, 4th reprint.
[11] Chand Lakshmi. Tel ki Pustak, Hindi Science University Mala, No. III, Vigyan Hunar Mala Office, Banaras City, 1916.

[12] Chand Lakshmi (ed.). Rang ki Pustak, 1916, Devi Prasad Agarwal, Shri Lakshmi Narayan Press, Banaras City, 1919, 2nd edition.

[13] Chand Lakshmi (ed.). Warnish aur Paint (Raughan Sazshi), Vigyan Hunar Mala Office, Banaras City, 1917.

[14] Chand Lakshmi. Tantukala, Mrs. Lakshmi Chand, Vigyan Hunar Mala Office, Banaras City, 1922.

[15] Devi Chandrakanta. Swasthya-Vigyan, Swasthya Mandir, Prayag, 1933.

[16] Dwiwedi Hazari Prasad (trans.) Rabindranath Tagore's Vishva Parichay, Indian Press Limited, Allahabad, 1937.

[17] Guha Subrat. Rashtriyata aur Sawadeshi Andolan, Abhiruchi Prakashan, Delhi, 1998.

[18] Gupta Mata Prasad. Hindi Pustaka Sahitya, Hindustani Academy, Allahabad, 1945.

[19] Gurukul Kangri Visvavidhalaya ka Sanshipt Itihas. 1901-1930, Prakashan Mandir, Haridwar (Year Missing).

[20] Joshi Shankar Raoji. Kalam Paiband, Vigyan Parishad, Allahabad, 1940.

[21] Joshi Shankar Raoji. Udyana, Ganga Pustakmala Pushp 11, Ganga Pustakmala Karyalaya, Lucknow, 1948, 3rd edition.

[22] Joshi Shankar Raoji. Varsha aur Vanaspati, Vigyan Granthmala No. 18, Vigyan Parishad, Prayag, 1923.

[23] Kapoor Kalidas and Tandon Prem Narayan (comp). Hindi-Sewi Sansar, 1944, Vidya Mandir, Lucknow, 1951, 2nd edition.

[24] Kochak Pandit Tejshankar. Krishi Shastra, Badri Printing Works, Bulandsahar, 1924.

[25] Mani Dinesh. Swatantrata Purva Vigyan Lekhan mein Prof. Phuldeo Sahay Verma ka Yogdan, In 
Shiv Gopal Mishra and Dinesh Mani (ed.), Vigyan Lokpriya Karan: Prarambhik Prayaas, Vigyan Prasar, New Delhi, 1997, pp. 20-31.

[26] Mishra S. Hindi Vigyan Sahitya ka Sarvekshan, Hindustani Academy, Allahabad, 2004.

[27] Mishra S. C. Hindustan mein Lakha, Superintendent Government Printing, Calcutta, 1914.

[28] Mishra Shiv Gopal. Vigyan Lekhan Ke Sau Varsh (Hundred Years of Science Writing in Hindi: 18501950): An Anthology of Selected Articles on Popular Science, vol. 1, Vigyan Prasar, New Delhi, 2001.

[29] Mishra Shiv Gopal. Vigyan Lekhan Ke Sau Varsh (Hundred Years of Science Writing in Hindi: 18501950): An Anthology of Selected Articles on Popular Science, vol. 2, Vigyan Prasar, New Delhi, 2003.

[30] Mohan Braj. Thos Jayamati, 1945.

[31] Mohan Braj. Niyamak Jyamiti: Vritt Samhita aur Shankav, II, Hindu Vishwavidhyalaya Granthmala No. 20, Birla Hindi Prakashan Mandal, Kashi Hindu Vishwavidhyalaya, Banaras, 1951.

[32] Mohan Braj. Ganitiya Kosh: Ganitiya Paribhasha aur Shabdavali, Chaukhamba Sanskrit Series, Banaras, 1954.

[33] Mohan Braj. Ganit ka Itihas, Hindi Samiti Granthmala No. 102, Hindi Samiti, Suchana Vibhag, Lucknow, 1965.

[34] Mohan Brij. What Lies Beyond? A Collection of True Supernatural Stories, Nine Books, New Delhi, 2016.

[35] Prasad Gorakh. Photography, Indian Press, Allahabad, 1931.

[36] Prasad Gorakh. Saur Parivar, Hindustani Academy, Allahabad, 1932.

[37] Prasad Gorakh. Aakash ki Sair, Indian Press, Allahabad, 1937.

[38] Prasad Gorakh. Lakdi ki Polish, Vigyan Parishad, Allahabad, 1940.

[39] Roy Benoybhusan. Unish Satake Bangla Bhasay Bigyancharcha, Naya Udhyog, Kolkata, 2002.
[40] Sarkar Sumit. Swadeshi Movement in Bengal, 190308, Peoples Publishing House, New Delhi, 1994.

[41] Satyaprakash. Sadharana Rasayana, Vigyan Parishad, Prayag, 1929.

[42] Satyaprakash. Shrishti ki Katha, Hindi Sahitya Sammelan, Prayag, 1937.

[43] Satyaprakash (ed.). Vaigyanik Shabd Kosh, 1, Bharatiya Hindi Parishad, Prayag, 1948.

[44] Satyaprakash. Samanya Rasayan Shastra, Bharti Bhandaar, Allahabad, 1951.

[45] Satyaprakash. Vaigyanik Vikas ki Bharatiya Parampara, Bihar Rashtra Bhasha Parishad, Patna, 1954.

[46] Satyaprakash. Prachin Bharat mein Rasayana ka Vikasa, Prakashan Shakha, Suchana Vibhag, Uttar Pradesh, 1960.

[47] Sen B. K. General Scientific Societies in British India, Indian Journal of History of Science, 52.2 (2017): 197-219.

[48] Sethi Nihalkaran and Satyaprakash. Vaigyanik Pariman, Vigyan Parishad, Prayag, 1928.

[49] Sethi Nihalkaran. Prarambhik Bhotiki, Indian Press Limited, Prayag, 1929.

[50] Sethi Nihalkaran (comp). Hindi Vagyanik Shabdawali: Bhotik Vigyan, Prakirnak Pustakmala No. 22 (1), Indian Press Limited, Prayag, 1929.

[51] Sethi Nihalkaran. Prarambhik Bhotik Vigyan, Hindu Vishwavidyalaya Granthmala, Kashi Hindu Viswavidhyalaya, Banaras, 1930.

[52] Sethi Nihalkaran. Chumbakatava Aur Vidhyut, Hindustan Academy, Allahabad, 1960.

[53] Sethi Nihalkaran. Sarvavyapi ether aur prakash siddhant, Vijnana, 3 (Dec.1917): 99-102.

[54] Sethi Nihalkaran. Vidhyut aur vidhyutkaran, Vijnana, 6.4 (Jan 1918): 155-63.

[55] Sethi Nihalkaran. Vidhyut spandan, Vijnana, 6.6 (Mar 1918): 245-50. 
[56] Sethi Nihalkaran. Effect of a retarding plate on white light interferometer fringes, Physical Review, 23.69 (Jan 1924).

[57] Sinha Mahesh Charan. Rasayan-Shastra athwa Hindi Chemistry, Indian Press, Prayag, 1909.

[58] Sinha Mahesh Charan. Vanaspati-shastra athwa Hindi Botany, Gurukul Kangri, Haridwar, 1911.

[59] Sinha Mahesh Charan. Vidhyut-Shastra athwa Hindi Electricity, Shri Raghvendra Press, Prayag, 1912.

[60] Sinha Mahesh Charan. India and the outside world, The Hindustan Review, 20 (Jan. 1908): 46-50.

[61] Sinha Mahesh Charan. Bijli, Saraswati, April 1910, Surya shakti, Vijnana, April, 1917 and Gandh vigyan, Madhuri, 1926, In S.G. Mishra (ed.), Hindi mein Vigyan Lekhan ke Sau Varsh, vol.1, 2001, pp.42-44; pp.88-91; pp.169-177 respectively.

[62] Tagore Rabindranath. Vishva Parichay, (trans.) Hazari Prasad Dwiwedi, Indian Press Limited, Allahabad, 1937.

[63] Tandon Rani. Anujivon ka pratham anweshek Leeuwenhoek, Vijnana, 61.4 (Jul 1945): 73-80.

[64] Tiwari Shitala Prasad. Krishi Vigyan, 1, Foreword by H. N. Batham, Ram Dayal Agarwal, Allahabad, 1926.

[65] Varma Mukund Swarup. Shishu Palana, Manoranjan Pustak Mala No. 43, Kashi Nagri Pracharini Sabha, Banaras, 1925.

[66] Varma Mukund Swarup. Swasthya-Vigyan, Kashi Hindu Vishwavidhyalaya, Banaras, 1931, 1st edition.

[67] Varma Mukund Swarup. Visha Vigyan, Kashi Hindu Vishwavidhyalaya, Banaras, 1932.

[68] Varma Mukund Swarup. Manava Sharira Ranchana Vijnana, 1938, Kashi Hindu Vishwavidhyalaya, Banaras, 1956, 2nd edition.

[69] Varma Mukund Swarup. Manava Sharira Rahasya, Sahitya-Suman-Mala-Pushp No. 5, 1928, Naval Kishore Press, Lucknow, 1949, 2nd reprint.
[70] Varma Phuldeo Sahay (comp). Hindi Vagyanik Shabdawali: Rasayana Shastra, Prakirnaka Pustakmala, No. 22, Indian Press Limited, Prayag, 1930.

[71] Varma Phuldeo Sahay. Sadharana Rasayana, 2 vols. Kashi Hindu Vishwavidhyalaya, Banaras, 1932.

[72] Varma Phuldeo Sahay. Mitti ke Bartan, Vigyan Parishad, Prayag, 1939.

[73] Varma Phuldeo Sahay. Prarambhik Angarik Rasayan, Nandkishore and Brothers, Banaras, 1948. 